\title{
REVIEW
}

\section{Making a Difference: The Contractual Contributions of Easterbrook and Fischel}

\author{
Ian Ayres $\dagger$
}

\begin{abstract}
The Economic Structure of Corporate Law. Frank H. Easterbrook \& Daniel R. Fischel. Harvard University Press, 1991. Pp viii, 370.
\end{abstract}

George Stigler reportedly once toasted Milton Friedman by saying: "Milton, if you hadn't been born, it wouldn't have made any difference." This multi-edged compliment might have implied that even if Friedman had not been born, the market place of ideas would have supplied his analysis. ${ }^{1}$ Judge Frank Easterbrook and Professor Daniel Fischel do not have the same faith in the market place of ideas for corporate law. Their view instead is that academics (and regulators) "are rewarded for novel rather than accurate beliefs" ( $p$ 208). Academics face weaker motivations than market participants because they don't suffer if they lobby for inefficient rules. ${ }^{2}$ Given these weakened incentives, the publication of The Economic Structure of Corporate Law is an especially noteworthy accomplishment. Easterbrook and Fischel have made a difference in our understanding of corporate law. By illuminating the economic structure of corporate decisions, their book provides a pow-

$\dagger$ Professor, Stanford Law School. Barry Adler, Jennifer Brown, David Friedman, Joe Grundfest, Bill Klein, Mitch Polinsky, Eric Rasmussen, and Roberta Romano provided helpful comments.

${ }^{1}$ An alternative explanation will be that in the long run the market will get it right whether or not someone explains why it will.

${ }^{2}$ Frank H. Easterbrook and Daniel R. Fischel, The Economic Structure of Corporate Law 100 (Harvard, 1991). All parenthetical page numbers in the text and footnotes refer to this text. 
erful guide to legislatures and particularly to courts crafting corporate rules. ${ }^{3}$

For readers who are put off by lavish praise I recommend skipping to the next paragraph. This may be the best book ever written about corporate law. ${ }^{4}$ The authors write clearly and creatively. Few corporate scholars today use the verb forms "crank up" or "fork over" (pp 4,7). Theirs is a style that has not been worn down by excessive law review editing.

At several points, the book stimulates readers by posing perverse conundrums. For example, in exploring the contours of the business judgment rule Easterbrook and Fischel ask:

why the same judges who decide whether engineers have designed the compressors on jet engines properly, whether the farmer delivered pomegranates conforming to the industry's specifications, and whether the prison system adversely affects the mental states of prisoners cannot decide whether a manager negligently failed to sack a subordinate who made improvident loans (p 94).

Instead of asking why so many businesses incorporate in Delaware, Easterbrook and Fischel ask why so few incorporate there (pp 21516). These conundrums propel the reader to find out if the authors really have an answer. It is fun to read.

It is also a book that needs to be read, even if you've already studied a number of Easterbrook and Fischel's well-known articles. $^{5}$ The book is not merely a compilation. I can verify their claim

${ }^{3}$ For example, in criticizing Donahue $v$ Rodd Electrotype Co., 367 Mass 578, 328 NE2d 505 (1975), Easterbrook and Fischel chide the court for failing to consider what the parties would have contracted for:

Among the firms that have written explicit contracts concerning the repurchase of shares, some allow selective repurchases from departing employees and some make repurchase mandatory. It would have been difficult to determine into which category a firm such as Rodd Electrotype fit. The court did not pursue this line, however .... (p 247).

4 At the very least it should be placed witlin the ranks of Robert Charles Clark, Corporate Law (Little, Brown, 1986), and Adolpl A. Berle and Gardiner C. Means, The Modern Corporation and Private Property (Harcourt, Brace, 1968). It also deserves a ligh ranking among those books applying economic analysis to legal issues. Discerning readers will notice that the book's title mirrors the work of another famous University of Clicago duo. William M. Landes and Richard A. Posner, The Economic Structure of Tort Law (Harvard, 1987).

s Portions of this book derive from the following articles by Easterbrook and Fischel: Corporate Control Transactions, 91 Yale L J 698 (1982); Voting in Corporate Law, $26 \mathrm{~J} \mathrm{~L}$ \& Econ 395 (1983); Mandatory Disclosure and the Protection of Investors, 70 Va L Rev 669 (1984); Limited Liability and the Corporation, $52 \mathrm{U}$ Chi L Rev 89 (1985); Optimal Damages in Securities Cases, $52 \mathrm{U}$ Chi L Rev 611 (1985); Close Corporations and.Agency Costs, 38 Stan L Rev 271 (1986). 
in the preface that "sections have been written from scratch, and all portions of the book (including those based on articles) have been substantially revised and updated" ( $p$ vii). The book-much more than the individual articles-integrates, for example, how the disciplining effects of debt, or shareholders' ability to diversify, affects the choice of optimal corporate rules.

The book also includes an excellent introduction to the technique of analyzing abnormal stock returns to measure how the market values particular corporate events. The book surveys the results of these "event" studies to measure the impact of a host of takeover maneuvers. This emphasis on empiricism is an admirable part of the authors' conviction that the choice of optimal rules will often turn on the relative size of competing effects. For example, in analyzing mandatory disclosure rules in securities law, Easterbrook and Fischel refreshingly admit that "we are left, for the moment at least, with arguments rather than proof" ( $p$ 314)..$^{6}$ The book thus avoids a common complaint about law efficiency analysis, because it does more than present a priori theories. ${ }^{7}$ Indeed, the authors stress at the outset: "The best structure cannot be derived from theory; it must be developed by experience" ( $p$ 5).

More importantly, the book displays how the authors' views on corporate law have evolved to a more detailed and balanced approach. Their strong-form behef that legislatures pass efficient statutes is now tempered by their acknowledgment that managerial "opportunism and the receptivity of state legislators to campaign contributions" can lead to inefficient legislation ( $p$ 218). Their strong-form belief that target managers should have an immutable duty to remain passive in the face of tender offers is now tempered by their acknowledgment that shareholders, at least at the time of the initial incorporation, should be allowed contractually to give their managers the ability to resist ( $p$ 174). In short, the book is even more reasoned and reasonable than the original articles. State legislatures sometimes pass inefficient laws; mandatory duties to disclose certain types of information may be efficient. The book is not a simple-minded paean to either the status quo or freedom of contract, even though the book argues that the contractual status of corporate law is by and large optimal. By openly discussing ex-

- Analogously, the authors argue that it is a close empirical question whether courts or managers should decide when to dismiss derivative suits ( $p$ 106).

' See, for example, John J. Donohue III and Ian Ayres, Posner's Symphony No. 3: Thinking About the Unthinkable, 39 Stan L Rev 791 (1987). 
ceptions to their general thesis, they more fully reveal the strength of and the limits to their argument.

Even with the substantially new and evolving materials in Easterbrook and Fischel's work, this is a difficult review to write. The individual articles that form the starting point of several chapters have given rise to an enormous literature ${ }^{8}$ and several independent debates. ${ }^{\circ}$ It is difficult to add to a slate that is far from blank. This review will focus on two overarching claims of the book: (1) the normative claim that efficient corporate law will usually be the set of hypothetical default terms that firms would contract for, and (2) the causal claim that competition among the states will generally drive corporate rules toward efficiency. In particular, I will argue that, while the hypothetical contract standard provides an important normative benchmark, it does not insure efficiency. The hypothetical contract is inconsistent with some of their examples of efficient default choice, and is an underspecified standard for legislative and judicial action. Instead of directly assessing the efficiency of the contractual equilibria induced by alternative default rules, the authors continue to run the efficiency race without a full stable of horses.

This review also suggests that the economic structure of contracting places important limits on the ability of legislatures to compete for corporate charters. The very barriers to private contracting also disempower state legislatures from providing superior contracts. Common law courts are the only institution that could possibly fill gaps better than the firms themselves. But the primacy of the common law in the competition for corporate charters is largely divorced from the "race to the top" as a causal mechanism that insures efficiency. Thus, the causal mechanism for the provision of efficient gap-fillers remains a topic for further research.

"A LEXIS search of the "LAWREV/ALLREV" file reveals more than 400 citations to Easterbrook and Fischel works. Their Corporate Control Transactions article is one of most cited Yale Law Journal articles in recent years. Fred R. Shapiro, The Most Cited Articles from the Yale Law Journal, 100 Yale L J 1449, 1464 (1991).

- With regard to target defenses to hostile tender offers, see David D. Haddock, Jonatban R. Macey, and Fred S. McChesney, Property Rights in Assets and Resistance to Tender Offers, 73 Va L Rev 701 (1987); Lucian Arye Bebchuk, Toward Undistorted Choice and Equal Treatment in Corporate Takeovers, 98 Harv L Rev 1695 (1985); Alan Schwartz, The Fairness of Tender Offer Prices in Utilitarian Theory, 17 J Legal Stud 165 (1988); Ronald J. Gilson, Seeking Competitive Bids Versus Pure Passivity in Tender Offer Defense, 35 Stan L Rev 51 (1982). With regard to mandatory disclosure, see John C. Coffee, Jr., Market Failure and the Economic Case for a Mandatory Disclosure System, $70 \mathrm{Va} \mathrm{L}$ Rev 717 (1984). 
For those that expect a roadmap, Section I addresses the authors' claims of the supremacy of default rules based on hypothetical contract provisions. Section II considers the usefulness of alternative default rules in two key areas of corporate law. Section III addresses the authors' causal claim concerning the incentives and behavior of state legislatures.

\section{The Limits of Hypothetical Contract Theory}

The book is aptly dedicated to Ronald Coase, whose pathbreaking The Nature of the Firm ${ }^{10}$ was the first work to ask "why firms differ from markets, and what determines when one stops and the other begins" ( $p$ 355). ${ }^{11}$ Coase contrasted the coordination of production within a firm by fiat to coordination by contract among independent contractors. ${ }^{12}$ The Economic Structure of Corporate Law builds, however, not only on Coase but also on the powerful subsequent extensions of the Coasean insights. In particular, more than thirty years after The Nature of the Firm, Armen Alchian and Harold Demsetz powerfully criticized the coordination by fiat theory of the firm:

It is common to see the firm characterized by the power to settle issues by fiat, by authority, or by disciplinary action superior to that available in the conventional market. This is delusion. The firm does not own all its inputs. It has no power of fiat, no authority, no disciplinary action any different in the slightest degree from ordinary market contracting between two people. ${ }^{13}$

This contractual reconception of the firm was later extended by Michael Jensen and William Meckling, who christened the corporation a "nexus of contracts."14

Easterbrook and Fischel's book in some ways represents a fitting culmination of this tradition. Theirs is the most sustained analysis of the contract rules governing this nexus of corporate

104 Economica (n.s.) 386 (1937).

1 The authors also dedicate the book to their parents, who we are told were "also necessary conditions of [the book's] existence" ( $p$ viii).

12 Richard A. Posner and Kenneth E. Scott, Economics of Corporation Law and Securities Regulation 2 (Little, Brown, 1980).

${ }^{13}$ Armen A. Alchian and Harold Demsetz, Production, Information Costs, and Economic Organization, 62 Am Econ Rev 777, 777 (1972).

${ }^{14}$ Michael C. Jensen and William H. Meckling, Theory of the Firm: Managerial Behavior, Agency Costs and Ownership Structure, 3 J Fin Econ 305 (1976). 
agreements. With characteristic clarity they state the book's central argument:

The normative thesis of the book is that corporate law should contain the terms people would have negotiated, were the costs of negotiating at arm's length for every contingency sufficiently low. The positive thesis is that corporate law almost always conforms to this model (p 15).

Throughout the book they persuasively argue why corporations should be allowed to contract for any preferred rules of corporate governance..$^{15}$ Although they readily admit that immutable rules are in limited instances necessary to protect external parties to the contract ( $p 23$ ), they skillfully deploy the standard arguments for contractual freedom because generally "[t]he corporation's choice of governance mechanisms does not create substantial third-party effects-that is, does not injure persons who are not voluntary participants in the venture" ( $p$ 17).

Descriptively, the rules of corporate law are essentially contractual because they are both adaptive and voluntary: stakeholders in the corporation via the articles of incorporation and other legal instruments can contract for alternative rules, and the participation of the stakeholder is not coerced-but must be induced by offering mutually advantageous terms (p 17). Thus, the authors conclude: "Votes may not look much like contracts, but the structure of voting-who votes, using what institutions-is contractual ..." (pp 4-5).

Having established that businesses should normally be allowed to contract around default rules of corporate governance, however, the authors are not as successful in defending their theory of how to choose the efficient default. Throughout the book, the authors argue that efficiency-minded lawmakers should fill gaps in the corporate contract with the hypothetical terms that "the parties would have contracted for had transactions costs been nil . . ." (p 250).

The authors argue that choosing defaults that the parties would have contracted for is efficient because it minimizes the costs of contracting:

[C]orporate law is a set of terms available off-the-rack so that participants in corporate ventures can save the cost of con-

15 'The corporate code in almost every state is an 'enabling' statute. An enabling statute allows managers and investors to write their own tickets, to establish systems of governance without substantive scrutiny from a regulator" (p 2). 
tracting. There are lots of terms, such as rules for voting, establishing quorums, and so on, that almost everyone will want to adopt. Corporate codes and existing judicial decisions supply these terms "for free" to every corporation, enabling the venturers to concentrate on matters that are specific to their undertaking ( $p$ 34). ${ }^{16}$

This argument provides a strong justification for off-the-rack rules in many commercial settings. The UCC's default rules saves parties from repeatedly bearing contract costs.

The reduction in contracting costs afforded by off-the-rack rules provides, however, a much weaker grounds for the efficiency of corporate law-especially the efficiency of corporate statutes. The costs of contracting around a cumulative voting default is insignificant for even the smallest publicly traded corporation. Moreover, virtually all corporations choose to state the preferred voting rule explicitly in their articles of incorporation. This leads to the conclusion that standard form off-the-rack rules have almost no effect on the transaction costs of publicly traded corporations.

The absence of this standard justification for off-the-rack rules increases the viability of alternative gap-filling theories. Because standard-form rules do not significantly economize on transaction costs in the corporate context, gap-filling rules that serve other purposes are more likely to be efficient.

\section{A. Penalty Defaults As Counterexamples}

Easterbrook and Fischel's hypothetical contracting standard does not always provide the best guide to choosing corporate rules. $^{17}$ Rob Gertner and I have argued elsewhere that choosing "penalty" defaults that the parties would not have contracted for could at times enhance efficiency, by forcing the parties to explicitly contract over the issue. ${ }^{18}$ By setting defaults that the parties

16 As I later point out, this traditional rationale for the usefulness of off-the-rack rules may not be nearly as powerful in the corporate charter context. See Section II.A..

17 The discussion here, which points to specific instances where the hypothetical contract standard produces tbe wrong default choice goes beyond a recent article of mine which argued that "strategic interactions may lead to inefficient corporate contracting (a) even in a world where there are numerous shareholder/investors coinpeting to make investments and (b) even when it is costless to contract around a given default." Ian Ayres, The Possibility of Inefficient Corporate Contracts, $60 \mathrm{U}$ Cin L Rev 387, 390 (1991).

18 Ian Ayres and Robert Gertner, Filling Gaps in Incomplete Contracts: An Economic Theory of Default Rules, 99 Yale L J 87, 94, 101-04 (1986). Easterbrook and Fischel have themselves perceived the beneficial information-forcing effects of penalty defaults. See, for example, Easterbrook and Fischel, $52 \mathrm{U}$ Chi L Rev at $113 \mathrm{n} 45$ (cited in note 5) (discussing 
do not prefer, penalty defaults can force parties to reveal beneficial information among themselves or to third parties. While the larger class of corporations may prefer these information-forcing rules (when they economize on the total costs of producing information and contracting), penalty defaults stand in stark contrast to Easterbrook and Fischel's theory of hypothetical defaults. Hypothetical defaults are designed to allow the corporate stakeholders to avoid explicit contracting, while penalty defaults are designed to induce explicit contracting.

At several points in their text, Easterbrook and Fischel apparently agree; they argue that certain default rules are efficient not because the parties would have contracted for them, but because they force parties to contract explicitly-and thereby reveal information.

\section{Undercapitalization.}

For example, the authors praise the default rule which allows even voluntary creditors to pierce the veil of limited liability if the firm is undercapitalized. Their defense of this rule sounds like a description of a classic penalty default:

Allowing creditors to look beyond the assets of the undercapitalized corporate debtor provides the debtor with the incentive to disclose its situation at the time of the transaction. The creditor then can decide not to transact or charge increased compensation for the increased risk ( $p$ 59).

Notice that the default of unlimited liability is not based on what the parties would have contracted for if transaction costs were nil. Easterbrook and Fischel suggest that with full information the parties would either agree to a contract with a higher interest rate or to no contract. There is no suggestion that the parties would have agreed that shareholders would retain unlimited liability.

\section{Equitable subordination.}

The authors suggest that the same considerations apply to equitable subordination, a doctrine under which a corporation's debt to shareholders may be subordinated to the debt claims of trade 
creditors and others who did not have actual knowledge of the shareholders' claims. The doctrine of equitable subordination acts as a penalty default because it "induces the insiders to make unusual patterns of equity and debt claims known" ( $p 60 \mathrm{n}$ 13). Again, the argument is not that shareholders and trade creditors would contract for equitable subordination if contracting were costless, but that the unwanted default of equitable subordination allows trade creditors to contract for a higher rate of interest.

3. Restricting involuntary dissolution.

A similar critique applies to the book's discussion of dissolution. The authors argue that the reluctance of common law courts to order dissolution of a firm is efficient, in part because it induces more efficient contracting:

Restrictive legal rules concerning involuntary dissolution also create incentives for the parties to establish less expensive methods of adjusting confiicts. They may do this when they start the firm, for example by including buyout provisions or voting agreements with some procedure for resolving deadlocks ( $p 240$ ).

Thus even if no firm would contract for restrictions on dissolution such default restrictions may be efficient because of their information-forcing effect.

\section{Partnership profits.}

A final example of a penalty default comes from Easterbrook and Fischel's analysis of how partnership profits are shared in the absence of a contrary agreement:

A familiar rule of partnership law is that unless partners agree otherwise, profits must be shared equally and no partner is entitled to a salary. The rationale for this rule is clear ..., it is relatively easy for partners to reach contractual agreements relating to particular contributions. If unequal division is necessary to provide an incentive to create gains, the partners can accomplish this by private agreement (p 143).

The authors do not argue that equal division of profits is normally the allocation that partners would opt for. Instead, the sharing default acts as a penalty default that induces partnerships to contract for more efficient profit-sharing plans. This rationale, however, might equally as well be applied to sharing gains among shareholders. The authors' own analysis of partnership profits 
might suggest that corporate managers have a default duty to share the gains from a takeover among all shareholders.

But Easterbrook and Fischel argue that shareholders "prefer legal rules under which the amount of gains is maximized, regardless of how the gains are distributed" (p 124). This empirical claim is not well substantiated. The authors' summary of the event study literature reveals that adopting fair-price amendments causes neither large nor statistically significant changes in stock price-indicating that stockholders do not believe that sharing in the takeover premium reduces the corporation's value (p 196). And even if the majority of corporations would not contract for gainsharing, the partnership analogy suggests that such a default might induce more efficient contracting.

Easterbrook and Fischel's own endorsement of the efficiency of penalty defaults is itself a strong counterexample to their claims that default rules should be what the parties would have contracted for. While the authors admit that mandatory rules are at times necessary to control externalities ( $p$ 23), they have not realized that default rules should at times depart from the hypothetical standard. Even though their own analysis supports the enlightened use of penalty defaults, they have not incorporated penalty defaults and the hypothetical contract standard into a more general theory of default choice.

\section{B. Directly Assessing Alternative Default Equilibria}

These examples of efficient penalty defaults refute the strong claim that the hypothetical standard should govern all default choices. But they do not represent the only circumstances in which the hypothetical standard might lead to inefficiency. As a general matter, it would be better to directly assess the efficiency of the contractual equilibria generated by alternative default rules. ${ }^{19} \mathrm{At}$ times the authors suggest this approach: "[W]hat should be worked out and supplied by corporate law is the rule that, if uniformly applied, will maximize the value of corporate endeavor as a whole" ( $p$ 35). But in practice, they seldom compare explicitly the efficiency of alternative default equilibria.

This defect is particularly evident in the book's analysis of insider trading. The authors put great emphasis on how corporations react to the current common law default rule (which they argue

19 See Jules Coleman, Risks and Wrongs 272 (forthcoming 1992); Ayres and Gertner, 99 Yale $L \mathrm{~J}$ at 108-18 (cited in note 18). 
permits insider trading), ${ }^{20}$ but fail to consider how corporation contracts would react to the alternative default prohibiting such trades. In particular, they find it important that corporations have failed to contract around this default: "Knowing of the rule [permitting insider trading in the absence of a contractual obligation], firms rarely attempted to prohibit trading by managers in possession of nonpublic information" (p 265). The autliors take the failure to contract around the common law default as evidence that a default allowing insider trading is efficient. They conclude that a fiduciary duty not to trade on inside information "should be imposed only as a constraint on conduct if there is very clear evidence that most parties would impose the constraint by contract if bargaining were costless" ( $p$ 270). ${ }^{21}$

This conclusion is especially suspect. The hypothetical standard does not provide a reasoned basis for creating a presumption ("very clear evidence") in favor of permitting such trades. The authors fail to consider how corporations would react to a default that prohibited insider trading. Is it Easterbrook and Fischel's belief that "most" firms would contract around such a rule? I frankly find it hard to believe if Rule 10b-5 liability were merely a default, that virtually any firm would affirmatively allow its managers to engage in insider trading. But if Easterbrook and Fischel are right, there should be minimal impediments in contracting to allow insider trading. The direct costs of contracting are especially trivial and it would be hard to believe that even mid-level management entrenchment would be difficult to overcome. Yet firms would not contract around a prohibition because the market might be inclined to heavily discount the shares of firms that affirmatively signalled the preference for insider trading.

Indeed, my "prior" is that many more firms would contract around a federal default which permitted insider trading. ${ }^{22}$ But at the very least, the insider trading setting poses the possibility that a majority of firms would fail to contract around either default

20 "At common law, managers and other insiders may trade the stock of public corporations on the basis of their inside information unless obliged by contract not to. Insiders need not disclose what they know. When federal securities laws do not apply (for example, when the transaction does not take place in interstate commerce), this is contemporary law" ( $p$ 264) (citations omitted).

${ }^{21}$ The authors acknowledge that no clear optimal rule exists in the insider trading context (p 263).

22 The book's reliance on current corporate contracts is especially misplaced because the failure of firms to contract around the current common law default can easily be explained by the presence of the immutable federal protection of Rule 10b-5. 
rule. When the contractual parties fail to contract around alternative defaults, the choice of the most efficient default will necessarily turn on a direct assessment of these competing equilibria.

\section{The Possibility of Tailoring}

At several points the authors suggest that courts should look to actual contractual practices in order to establish the dominant contractual terms as the default. ${ }^{23}$ But if a majority of firms would fail to contract around either insider trading rule, then there is no single dominant rule to choose. This ambiguity in the insider trading context is part of a larger ambiguity in the authors' hypothetical contracting approach.

The authors fail to address whether the hypothetical default rules should be tailored or untailored. Should courts, for example, endeavor to discover the contract that the specific corporate stakeholders would have contracted for, or should it seek the "majoritarian" default that most parties would have wanted? At times the authors recommend each type of rule without providing any theory for when corporate rules should be tailored.

In the introduction, Easterbrook and Fischel expressly propose untailored, "off-the-rack" standards that "most venturers would have chosen" ( $p$ 15) (emphasis added). Yet at several points in the text they suggest that courts should fill the gaps in incomplete contracts with provisions tailored to "what the [specific] parties would have contracted for had transaction costs been nil." For example, in analyzing the court's decision in Donahue $v$ Rodd Electrotype Co. ${ }^{24}$ the book suggests looking at whether the specific corporate stakeholders in question would have contracted to give all shareholders an equal opportunity to participate in share repurchases.

Completely overlooked in all of [the court's] rhetoric was the basic question-which outcome would the parties have selected had they contracted in anticipation of this contingency? . . . Among the firms that have written explicit contracts concerning the repurchase of shares, some allow selective repurchases from departing employees and some make repurchase mandatory. It would have been difficult to

2s "If larger firms elect not to address a subject through contract, then it is best to conclude that the presumptive rule does not need tinkering" (p 252).

24 367 Mass 578, 328 NE2d 505 (1975). 
determine into which category a firm such as Rodd Electrotype fit (p. 246-47).

Tailored hypothetical defaults have the advantage that they strive to give each firm the corporate contract it would have bargained for if negotiations were costless. But, as the authors admit, it may be difficult accurately to implement the tailoring. Untailored "majoritarian" defaults, on the other hand, act as penalty defaults when imposed upon minority corporations. Plus, as the insider trading example shows, there may be situations where there is no unique majoritarian default. It is left for future analysis to weigh these competing influences. This failure to provide a theory for the appropriate tailoring of default rules substantially undermines the book's power to predict the substantive contours of efficient corporate law.

\section{An Efficiency Justification For Ex Post TaIloring}

These unspecified determinants of tailoring are especially important because only courts can implement meaningful tailoring. Explicitly addressing whether default rules should be tailored or "off-the-rack" will accordingly have important implications for the division of power between courts and legislatures. This section argues that in the corporate context efficiency-minded lawmakers should often favor a specific kind of ex post tailoring, even when a majority of corporations would prefer untailored contractual obligations. In particular, Easterbrook and Fischel's preference for majoritarian default rules ignores important forces that argue for ex post balancing of case-specific costs and benefits.

\section{A. Why Muddy Default Rules Can Make Sense}

As argued above, the standard economic defense of off-therack rules provides an extremely poor explanation for the current corporate law defaults. The standard form contract provided by the UCC conserves the gains from trade by reducing the costs of drafting individual contracts when buyers and sellers participate in relatively small, discrete transactions. The reduction in contracting costs afforded by off-the-rack rules provides, however, a much weaker ground for the efficiency of corporate law, especially the efficiency of corporate statutes.

This is an essential part of Bernie Black's argument that state corporate law is "trivial"-because the choice of alternative default rules in many contexts would have no impact on the equilibrium 
rules governing corporations or the costs of contracting. ${ }^{25}$ It is absurd to think that the majority of Fortune 500 companies prefer Delaware over other states that have enabling statutes because Delaware's Corporations Act provides the best untailored rules.

Easterbrook and Fischel partly recognize the weakness of this "standard-form" contract justification for majoritarian rules. They pose the conundrum: "Why not just abolish corporate law and let people negotiate whatever contracts they please? . . . Why don't law firms . . . compile sets of terms on which corporations may be constructed?" (pp 34-35). In answering these questions, the authors explicitly recognize that courts play an important role in filling gaps ex post. ${ }^{26}$

If parties want to contract for a non-contingent obligation, they can easily contract for such a rule ex ante-regardless of the initial default. This is the central point of Bernie Black's triviality thesis. But the corporation is a set of long-term relational contracts and there are substantial obstacles (i.e., costs) to creating contracts that maximize the gains from trade in all states of the world. In the modern parlance of economics, it is effectively impossible for corporations to write contracts that are "sufficiently state contingent."27 Courts can promote efficiency by imposing contingent contractual obligations ex post that corporate stakeholders are in practice unable to contract for ex ante.

Easterbrook and Fischel recognize that ex post gap-filling by courts is sometimes more efficient than explicit ex ante contracting by the parties, but they fail to see that efficient gap-filling will often entail an ex post tailoring of contractual obligations. The non-trivial default rules of corporate law will often be muddy gapfillers that ask courts to balance the costs and benefits of contractual obligations under particular contingencies. Muddy defaults make contractual obligations contingent on circumstances ("states of the world") that are verifiable by courts ex post, but prohibitively costly to identify ex ante. Because corporations cannot practicably contract for these muddy rules in advance, courts have the

${ }^{25}$ Bernard S. Black, Is Corporate Law Trivial?: A Political and Economic Analysis, 84 Nw U L Rev 542 (1990).

28 "Court systems have a comparative advantage in supplying answers to questions that do not occur in time to be resolved ex ante. Common law systems need not answer questions unless they occur. This is an economizing device" ( $p$ 35). Jack Coffee has powerfully analyzed the importance of courts in implementing rules of corporate governance. John C. Coffee, Jr., The Mandatory/Enabling Balance in Corporate Law: An Essay on the Judicial Role, 89 Colum L Rev 1618 (1989).

${ }^{27}$ See Ayres and Gertner, 101 Yale L J at 731 (cited in note 18). 
possibility of filling gaps with terms that are not "trivial." Default rules that make contractual obligations contingent on events that are costly to contract for ex ante might be efficient even if they are only preferred by a minority of businesses.

In simple terms, it may be cheaper for corporations to contract for crystals than mud. ${ }^{28}$ If the default rule involves courts in muddy ex post balancing of the activity's costs and benefits, corporations that prefer unconditional rules (that unconditionally either allow or prohibit particular management behavior) can cheaply contract for them. In contrast, if the default rule unconditionally allows or unconditionally prohibits that behavior, it will be much more difficult for the parties to contract for a muddy rule which asks courts to make contractual obligations fully contingent on future states of the world.

Corporations desirous of muddy ex post determinations could cheaply insert ex ante muddy provisions that allow managers to engage in an activity when it is "reasonable" or when "the costs exceed the benefits" or when it is "in shareholders' interest." However, forcing even a minority of corporations to opt for this kind of language is likely to be less efficient than starting with a muddy (ex post conditioning) default and forcing a majority of corporations to contract for an unconditional provision. Because the ex ante formulations of reasonableness by individual corporations can take so many different forms, there is a much smaller likelihood of developing a coherent (and therefore valuable) precedential base.

Contracting around an unconditional default rule by adopting some variant of a "reasonableness" provision would accordingly be attended by much more uncertainty than failing to contract around a muddy "reasonableness" default.". In the former instance, the multiplicity of possible contractual provisions is likely to splinter the precedents and deter mud-seeking corporations from contracting for their preferred rule. ${ }^{30} \mathrm{By}$ contrast, few firms

${ }^{28}$ This terminology is taken from the seminal analysis of these two types of property entitlements. See Carol M. Rose, Crystals and Mud in Property Law, 40 Stan L Rev 577 (1988).

20 An important corollary to the foregoing argument is that when different firms desire different types of muddy ex post tailoring it will be difficult for the individual jurisdictions to provide multiple forms of tailoring. It will be just as difficult for firms to contract around one muddy default for another as it is to contract around an unconditional default for a muddy rule.

so Jeff Gordon similarly argued that immutable rules may be efficient if they preclude an inefficient splintering of precedent that might take place under an enabling rule. Jeffrey N. Gordon, The Mandatory Structure of Corporate Law, 89 Colum L Rev 1549, 1565-66 (1989). 
should be deterred from contracting around a muddy default. Firms that want unconditional contractual duties can contract-at a trivial cost-for provisions that unconditionally allow or prohibit particular types of management behavior. ${ }^{31}$

Moreover, muddy defaults may lead to less judicial nullification than defaults that carve out unconditional managerial obligations. While courts may have a tendency ultimately to nullify any private attempts to modify the default obligations of contracts, it may be that courts are less likely to nullify explicit unconditional provisions than attempts to contract for muddy ex post determinations.

This analysis of muddy defaults contrasts sharply with Easterbrook and Fischel's recommendation of majoritarian default rules. Even if only a minority of corporations prefer muddy rules, it can be efficient to choose a muddy default, because it is cheaper to make the majority of firms contract ex ante for an unconditional rule than to make a minority of firms incur the substantial costs and uncertainty of contracting for mud. Untailored majoritarian defaults have their strongest efficiency rationale when it is costly to replicate them explicitly by contract. This again is the powerful justification for the UCC. Black's triviality hypothesis suggests, however, at least with regard to publicly traded corporations, that it is virtually costless for corporations to contract ex ante for unconditional entitlements.

The costless ability to contract for untailored rules argues that efficient default settings should be skewed toward rules that are more expensive to contract for. In the unique setting of corporate contracting, the virtually costless ability to formulate unconditional provisions in the corporate charter suggests an efficiency bias toward default rules that are more expensive to write ex ante. $^{32}$

31 There may also be multiplicities of crystalline (unconditional contractual) rules. Unconditional contracts, however, are not as ambiguous as muddy rules and hence are likely not to require a unified precedential base to be a reliable guide to action.

${ }^{32}$ The virtual costlessness of ex ante contracting for untailored rules also explains why penalty defaults are especially likely to be efficient in the context of publicly traded corporations. Parties have incentives to explicitly contract around penalty defaults. In the context of discrete commerce, this additional contracting might represent a significant portion of tbe gains from trade. The costs of ex ante contracting for publicly traded corporations are so small, however, that the costs of additional contracting induced by penalty defaults are not a countervailing factor limiting their usefulness.

There may be circumstances, however, where there is a conflict between penalty defaults (which are likely to induce all firms to contract for unconditional or crudely conditional obligations) and muddy defaults (which allow courts to impose more complicated con- 
These disparate costs of contracting for crystals and mud also undermine the inferences that Easterbrook and Fischel would draw from the contractual reaction to particular defaults. The book argues: "If larger firms elect not to address a subject through contract, then it is best to conclude that the presumptive rule does not need tinkering" ( $p$ 252). The foregoing analysis suggests that this argument is only partially correct. If publicly traded firms fail to contract around a muddy default in favor of an unconditional obligation or entitlement, then the foregoing analysis would support the authors' inference that the muddy rule is superior. ${ }^{33}$ Yet the failure to contract around either a muddy or a crystalline default in favor of another form of muddy contractual condition should not give rise to the same inference in favor of the status quo. Because of the substantial difficulties that even publicly traded firms will have in affirmatively contracting for fully contingent obligations or entitlements, the failure of firms to try should not persuade policy makers that corporations do not want muddy default rules.

To make this argument more concrete the next sections explore the possible advantages of using muddy defaults to govern managers' fiduciary duties in two important contexts: the duty of care for decisions in the ordinary course of business and target management responses to hostile tender offers. These examples are particularly well-suited to highlight our differences in approach-not only because they represent core issues of corporate governance, but because they afford an opportunity to analyze the three categories of defaults that might govern management behavior: conditional authority, unconditional prohibition, and unconditional authority. While my approach suggests that muddy defaults (conditional authority) may be efficient both with regard to the duty of care and target responses to hostile tender offers, Easterbrook and Fischel essentially argue that efficient defaults should: (1) unconditionally prohibit managers from resisting a hostile bid, but (2) unconditionally allow managers authority to act in the ordinary course of business. Contrasting our methods of default choice further qualifies the book's normative argument for the use of majoritarian defaults and provides important examples where

ditional obligations). For the reasons discussed above, few firms would be able to contract around a penalty default for a muddy obligation. On the other hand, muddy ex post tailoring might not give stakeholders sufficient information for efficient ex ante reliance.

ss Even here, however, the unconditional rule may have desirable information forcing properties. See note 18 and accompanying text. 
corporate law is not trivial, because the choice of presumptive rules does affect the efficiency of corporate governance.

\section{B. The Authors' Incomplete Defense of a Passivity Default}

Easterbrook and Fischel's analysis of hostile tender offers is one of the several places in the book where recent scholarship has caused the scholars to modify their beliefs. Although in 1982 the authors argued that target management should have an immutable duty to remain passive when their corporation is subject to a hostile takeover, ${ }^{34}$ they have grudingly conceded that passivity should merely be a contractual default that can be contracted around: "the optimal legal rule prevents resistance unless expressly authorized by contract ex ante" (p 174). Their concession is attributed in part to the excellent article by Haddock, Macey and McChesney, ${ }^{35}$ and in part to their realization that advocating passivity as merely a default is more consistent with their larger thesis that corporate contracts should be enforceable. Yet the authors have not provided an adequate defense of the passivity default. As before, the authors are persuasive that the rule should be governed by a default, but don't adequately discuss the effects of alternative defaults.

They make much of the fact that firms fail to include contractual provisions that facilitate an auction:

It is easy to write the articles of incorporation (or poison pill securities) to facilitate auctions while tying managers' hands. For example, instead of writing a poison pill that may be redeemed if and only if the managers choose to do so, the firm could have a pill that cancels itself if an all-and-any offer is open for ninety days. ... Yet no firm has adopted it-not on going public, not later. ... Nonexistence of securities said to be beneficial to investors is telling ( $p$ 205). ${ }^{36}$

Yet the book might have just as easily drawn a similar inference about the failure of corporations to precommit contractually to passivity. We do not see, for example, contractual provisions prohibiting managers from putting poison pills in place to resist hostile tender offers. No firm adopts these contracts-"not on going public, [and] not later" (p 205). By Easterbrook and Fischel's

${ }^{34}$ See Easterbrook and Fischel, 91 Yale L J 698 (cited in note 5).

35 Haddock, Macey, and McChesney, $73 \mathrm{Va} \mathrm{L} \mathrm{Rev} \mathrm{at} 701$ (cited in note 9).

${ }^{36}$ But see earhier in the book, where the authors argue that it would be difficult to write into articles of incorporation a provision that imposed on target management the duty to conduct an auction (p 169). 
logic this should be telling evidence that corporations do not want the passivity default rule.

Instead the authors emphasize that "firms go public in easyto-acquire form: no poison pill securities, no supermajority rules or staggered boards" ( $p$ 205). Yet this observation fails to explain why firm after firm decides to retain the option to later install the provisions that Easterbrook and Fischel believe are inefficient. The authors could have employed their persuasive expositional ploy of asking why firms don't go public in even easier to acquire forms by precommiting to passivity. For example, a publicly traded corporation might provide that its board of directors will approve any cash merger offer that exceeds the current stock price by 10 percent. The book ignores this possibility; the exposition is thus guilty of including only a selective analysis of contractual inertia.

A more satisfying way to evaluate the efficiency of alternative default rules is to directly consider what kinds of contracts we might expect under the different rules. As discussed above, a muddy default rule that asks courts to balance ex post the reasonableness of managerial action is likely to be more efficient than an unconditional default of passivity-at least with regard to firms that have gone public or recapitalized in the 1980s. The initial creators of a corporation can much more easily contract around a muddy default and prohibit poison pills than contract around a passivity default and allow only reasonable management resistance.

Easterbrook and Fischel seem to appreciate the substantial costs of writing fully contingent contracts, but fail to see how these costs might militate toward letting courts fill gaps with more contingent ex post rules: "Agency relations (as between managers and equity investors) exist precisely because full contractual specification is unbearably costly" ( $p$ 168). These costs of making fully contingent contracts apply, however, with equal force to managers' authority to engage in defensive takeover tactics as they do with regard to other aspects of the agency relationship. Because it is more costly to contract for contingent entitlements than non-contingent entitlements, a small demand for making management resistence contingent on the surrounding circumstances can make a muddy "reasonableness" default efficient. While Easterbrook and Fischel have abandoned their previous stance that target passivity should be immutable, their analysis doesn't fully pursue the consequences of heterogeneous contracting, i.e., the possibility that different standards might maximize different firms' values. 
Even if Easterbrook and Fischel are right that a majority of firms would prefer managerial passivity, the muddy default can enhance efficiency. Those preferring unconditional passivity (i.e., no poison pills) can contract for it at virtually no cost, while those preferring a muddy reasonableness test are more likely to achieve their goal (and at a much lower cost) under a muddy default. ${ }^{37}$

Evaluating management's ability to issue poison pills under a default of ex post reasonableness may have costs, however, if at the time of initial capitalization the promoters didn't consider the possibility of precomitting to passivity and if subsequent managerial entrenchment forestalled efficient amendment of the corporate governance contract. But at least prospectively, firms that go public or recapitalize are certain to consider the possibility of future tender offers and takeover defenses. And as the authors persuasively argue, the possible self-serving entrenchment of incumbent managers is at its weakest when a firm substantially recapitalizes. Accordingly, within the authors' own framework there should be no substantial barriers to contract around a "reasonableness" default for firms that substantially recapitalize in the future.

This apology for using ex post muddy defaults can also be seen as a possible apology for Delaware's intermediate standard of review-which allows target management to maintain the threat of non-cooperation "only if they show they [have] good reasons to do so" (p 206). ${ }^{38}$ However, as emphasized above, firms will face considerable costs in trying to replace one muddy rule with another. Thus, while the foregoing suggests that a muddy rule may well be efficient, it does not indicate which muddy rule is likely to maximize social wealth-and counter to Easterbrook and Fischel, I do not believe that looking at a single contractual equilibrium is likely to provide much information about which type of muddiness is optimal.

${ }^{37}$ The possibility of efficient "minoritarian" rules is discussed explicitly in Ayres and Gertner, 99 Yale $L \mathrm{~J}$ at 108-18 (cited in note 18).

${ }^{38}$ See also Ronald J. Gilson and Reinier Kraakman, Delaware's Intermediate Standard for Defensive Tactics: Is There Substance to Proportionality Review?, 44 Bus Lawyer 247 (1989). The Delaware Supreme Court's decision in the Time Warner case calls into question whether target management now faces this higher level of scrutiny, and has given rise to the possibility that target management can "just say no" to the hostile takeover. See John Greenwald, All Hitched Up and Ready To Go: Time Warner Debuts as the World's Largest Media Concern, Time 39 (Aug 7, 1989). 


\section{The Authors' Uneasy Apology for the Duty of Care}

The authors' thesis concerning fiduciary duties is consistent with their larger claim that hypothetical default rules are efficient: "Socially optimal fiduciary rules approximate the bargain that investors and managers would have reached if they could have bargained (and enforced their agreements) at no cost" (p 92). They suggest that the substantial deference given to managers is not so much caused by the incompetence of judges as it is by the competence of market forces, including the threat of replacement, to police the agency relationship. Judges are called upon to make difficult factual determinations in a number of other contexts-where market forces are not in play to independently constrain the private decisionmakers. In the context of corporate governance, however, Easterbrook and Fischel argue that parties would contract for less judicial scrutiny of management behavior because the agency relationship can be enforced more efficiently by threatening to fire managers who shirk: "Some combination of the fiduciary principle with a mechanism to replace the managers makes extensive discretion work the rest of the time." (p 168). The contours of fiduciary duties placed upon management for Easterbrook and Fischel are defined to capture those limited situations where the judicial enforcement of the agency relationship is more efficient than private market enforcement.

The foregoing argument provides a powerful description of the duty of loyalty. Yet the current duty of care doctrine remains a conundrum. The authors argue that "there is no sharp line between the duty of care and the duty of loyalty" ( $p$ 103). However, their only examples of situations where judicial scrutiny is cost effective involve duty of loyalty problems of the " take the money and run' sort, in which subsequent penalties through markets are inadequate" ( $p$ 103). The authors are left confronting a legal world in which the duty of care exists even in situations in which the market would seem to provide the necessary discipline.

Thus, their descriptive claim that existing law approximates defaults that most firms would contract for is not supported by their analysis, which seems to indicate that most firms would not contract for a duty of care. In a sense, their argument proves too much. They never identify a situation in which shareholders would want to hold managers liable for violating a duty of care. So within the book's paradigm, a no-duty-of-care default would seem to be efficient. 
The evidence that they marshal does not support their thesis that fiduciary rules are efficient. For example, they argue that "[i]ndemnification and insurance allow firms to contract around liability rules when markets are cheaper than courts" (p 105). Yet, given the tremendous cost of shareholder litigation, these methods of contracting around manager liability are much more expensive than a default which abolishes any duty of care liability. Even the Delaware legislature's response to the notorious Trans Union finding of liability ${ }^{38}$ is not wholly consistent with their theory of default choice. Because while Delaware now allows firms to eliminate damages for liability in duty-of-care cases, it retains the default of liability which under their theory is not for what people would contract. ${ }^{40}$

It should be troubling to the authors that many Delaware firms do not choose to avail themselves of this opportunity to opt out of the duty of care liability. Given the real costs of derivative suits, indemnification and insurance of managers are not perfect substitutes for waiving duty of care liability. In sum, their descriptive theory fails to adequately explain this core, non-trivial area of corporate law: (1) many states don't allow corporations to efficiently waive duty-of-care liability; (2) no state has enacted the nohability default; and (3) in states that allow corporations to waive liability, many corporations haven't availed themselves of this opportunity.

A better explanation for current practice might be found in the foregoing argument for muddy rules. While the business judgment rule grants managers substantial autonomy, it remains an empirical question whether there are duty of care issues where minimal judicial scrutiny is cost effective. Given the reluctance of many Delaware firms to waive this form of managerial liability, it is far from clear that fiduciary duties should be limited solely to "spectacular, one-shot appropriations" involved in duty of loyalty cases ( $p$ 103). Moreover, because it is much easier to opt for an unconditional waiver than to specify the conditions under which judicial scrutiny is cost effective, retaining a muddy default where courts judge reasonableness ex post may be efficient even if most firms would prefer an unconditional waiver. The authors' insight that self-enforcement of the agency relationship may be more effi-

39 Smith v Van Gorkom, 488 A2d 858 (Del 1985). See Jonathan R. Macey and Geoffrey P. Miller, Trans Union Reconsidered, 98 Yale L J 127, 135 (1988) (arguing that the case is better viewed as a specialty of tender offer law).

10 8 Del Code Ann § 102(b)(7) (1991). 
cient than judicial enforcement still should provide a powerful guiding force in determining when to second-guess managerial decisions. But muddy defaults that make managerial liability turn on non-contractible contingencies are more easily amended by private contracts waiving liability than a default that unconditionally waived management liability. Again, the important decision for corporate law might well be to choose the most efficient rule within the class of muddy defaults.

\section{The Contractual Limits to Competttive Federalism}

The triviality of ex ante contracting for non-contingent rules not only biases the selection of defaults toward muddy rules, it also has profound implications on legislatures' ability to compete for charter revenues. Charter competition by legislatures is the linchpin of Easterbrook and Fischel's causal explanation for why corporate rules tend to be efficient. The authors' discussion is clear and tempered. Competition among states for corporate charters provides only a strong tendency for efficient rulemaking:

Competition is a good mechanism but need not be perfect. Delaware can win the race for revenues by being "best" without being "optimal"-and given the impossibility of optimality, satisficing rather than optimizing is likely. The race will not be for the bottom; the long-run pressures will favor investors over managers; but the movement toward long-run equilibriums may be erratic ( $p$ 218). ${ }^{41}$

The authors provide strong reasons why competition among state legislatures will lead to the enactment of enabling statutes. On closer inspection, however, competitive federalism is unlikely to be able to insure that legislatures will choose the efficient gap-filling rules.

Easterbrook and Fischel argue that Delaware's success comes from three sources: "its enabling statute, its large body of precedents and sophisticated corporate bar, and its credible commitment to be receptive to corporate needs because of the large percentage of its state revenues derived from franchise fees and taxes"

41 For example, the authors openly address the inconsistency of the race-to-the-top thesis with the adoption of antitakeover statutes:

If the claim is that the competition among states for incorporations always produces the optimal result, it stands refuted. But if the thesis is that competition creates a powerful tendency for states to enact laws that operate to the benefit of investors (the opposite of the Cary view), it is alive and well (p 222). 
(p 213). The foregoing discussion of the substantial contracting indicates, however, that it is unlikely that Delaware's enabling statute gives it any advantage over other states that allow contractual freedom. Delaware's advantage among states with enabling statutes is much more likely to come from its ability to implement muddy fiduciary defaults-what Easterbrook and Fischel term "its large body of precedents and sophisticated corporate bar" ( $p$ 213). ${ }^{42}$

As emphasized before, the normal savings in transaction costs that stem from providing off-the-rack rules is of de minimis importance with regard to publicly traded corporations. The normal efficiencies of providing standard-form ex ante rules drop out of the efficiency analysis. The substantive provision of the Delaware Corporate Code is relatively short. ${ }^{43}$ It would be a trivial cost for Fortune 500 companies to write these contracts themselves. From this perspective, Delaware might be equally attractive in comparison to other "enabling" jurisdictions if it repealed its corporate statutes and simply said that courts should enforce all contracts, thus leaving it to the courts to choose gap-filling rules for corporate contracts as well.

Even if the authors are right that competition gives state legislatures an incentive to pass efficient corporate rules, the legislatures face important barriers in accomplishing this end. In particular, legislatures face the same barriers that firms face in trying to write fully contingent contractual provisions. In choosing defaults, legislatures are effectively limited to choosing among the class of untailored and unconditional entitlements and obligations. To put the point most simply, any contractual provision that a legislature could write ex ante, corporations could write better. The costs of writing down unconditional entitlements is trivial for publicly traded corporations and they know better what unconditional rules best fit their needs.

42 The third proposed source stems from Roberta Romano's seminal article, Law as Product: Some Pieces of the Incorporation Puzzle, 1 J L Econ \& Org 225 (1985). Bernie Black discusses the limits of Roberta Romano's precommitment thesis, in particular questioning one critical aspect of her work, her proposition that the cost to corporations of relocating to other jurisdictions is high. Black, $84 \mathrm{Nw} \mathrm{U} \mathrm{L} \mathrm{Rev} \mathrm{at} \mathrm{586-89} \mathrm{(cited} \mathrm{in} \mathrm{note} \mathrm{25).}$ Black's explanation of Delaware's dominance turns on the expertise of participants in resolving disputes. Id at 589. In contrast to this review, however, Black argues that "judges are bit players" when it comes to providing substantive legal rules. Id at 585 . Unlike Black's analysis, this review has argued that courts can fill gaps with non-trivial muddy rules that the corporations can write down ex ante.

438 Del Code Ann $\S 101$ et seq (1991). 
The corollary to this proposition is that anything that corporations can't contract for at a trivial cost, legislatures won't be able to provide. As discussed above, corporations may have a desire for corporate governance rules that are more fully contingent than can be practicably contracted for. The implementation of these tailored and muddy defaults is a core area where default choice is not trivial. But legislatures are disempowered from providing the rules in the very situations where the choice of default matters. Legislatures might want to race to the top, but the economic structure of contract law disempowers them from providing more than trivial standard-form rules that the private parties could have replicated themselves without any cost worth mentioning. The very forces that keep firms from being able to contract about contingencies ex ante constrain state legislatures as well. Thus, a perplexing problem with the race to the top theory is that it doesn't explain the core attraction that one enabling state can have over another.

Courts then provide a unique source for providing non-trivial defaults. Because courts often need to fill gaps when unusual problems arise, the common law process holds out the possibility of providing muddy contractual terms for which the parties could not practicably contract. Easterbrook and Fischel are not unmindful of the importance of court decisionmaking, ${ }^{44}$ but do not adequately address how legislative disempowerment undermines the "race to the top" as a causal story of corporate law efficiency.

Given legislatures' incapacity to write non-trivial rules, the race to the top can have much more limited impact. First of all, competition ensures that legislatures will enact default provisions and not immutable rules. Statutory competition may similarly prevent common law courts from imposing immutable standards. From this perspective, the race to the top may be more important for deterring legislatures from doing immutably bad things rather than for inducing affirmative behavior that enhances the efficiency of corporate governance. There may, however, be a few legislative powers that affirmatively enhance non-trivial lawmaking.

Legislatures might guide the judicial gap-filling process. For example, if a muddy default is more efficient than unconditional contractual entitlements, then the legislature may be effective in preventing common law courts from imposing an unconditional de-

" "The debate about whether the common law is efficient, or could be so through "invisible hand' processes, is no less germane here" ( $p$ 217). "Court systems have a comparative advantage in supplying answers to questions that do not occur in time to be resolved ex ante" ( $\mathrm{p} 35$ ). 
fault entitlement. Thus, a statutory provision might preempt the unconditional Donohue rule with a default standard tied to instances of "oppression" or "unreasonableness." Legislatures will have more trouble, however, directing courts to change from one muddy default to another. Because muddy rules cannot be written down in advance, legislatures can only send broad messages for how courts should carry out the contingent gap-filling. Consider, for example, the difficulties a legislature would face in changing the contours of managers' fiduciary duties. Yet arguably the spate of stakeholder constituency statutes try to do just this by directing courts to consider new categories of information when addressing whether management had a contingent right to behave in a specific way. Legislatures have other, less problematic means of competing for corporate charters. For example, they might offer a menu of safe harbor provisions that firms could contract for. The statute would supply the sufficient conditions (magic words) that would allow corporations to supplant default provisions of corporate governance with alternative contractual defaults. A menu of safe harbors might allow precedent to develop around a discrete number of different balancing standards. Clearly announcing what words are sufficient to establish alternative contractual regimes would also enhance the reliability of a state's corporate law and hence the desirability of that jurisdiction. Enlightened use of contractual menus can serve to make the choice of default rule less important. ${ }^{45}$

The legislative disempowerment thesis proposed in this Section accordingly has some caveats. The Delaware legislature can do some affirmative things to enhance the attractiveness of its legal product. The main thrust of the disempowerment thesis stands unrebutted however. Legislatures face significant constraints in competing on the basis of default choice. Paraphrasing a song from "Annie Get Your Gun," the central insight of this Section might be

4s The crucial assumption in the foregoing analysis of muddy defaults was that it would be more expensive for firms to contract for mud around a crystalline default than it would be to contract for crystalline entitlements around a muddy default. The costs of contracting for ex post judicial scrutiny (say, of the reasonableness of managers' actions) would be much lower if parties could opt for a body of precedent by opting for the magic words announced in a statute. Thus, if Delaware passed a statute that announced a default of target passivity hut allowed corporations to contract for traditional fiduciary duties by using particular words in the corporate charter, it would he much more difficult to argue that the traditional muddy default is superior to the crystalline default proposed by the authors, since the cost of contracting around the crystalline default for mud would be less. 
stated: anything legislatures can do, firms can do better. ${ }^{46}$ Counter to "race to the top" theories, courts must play the crucial role in differentiating the law among competing enabling statutes-for the simple reason that the courts are the only institution that are structurally capable of supplying non-trivial gap-filling rules.

\section{Conclusion}

The monumental success of The Economic Structure of Corporate Law stems in large part from its balanced and tempered argumentation. The authors show an admirable willingness to concede that: (1) state corporate law is sometimes inefficient, and (2) the efficiency of a particular rule is often contingent on competing empirical effects. Their thesis that the corporate law tends to be the set of default rules that parties would have contracted for is made all the more powerful by their ability to explain why there are both efficient and inefficient departures from the hypothetical default standard. While the authors' insights have always been penetrating, the book represents an evolution toward a more balanced and defensible theory of corporate law. ${ }^{47}$

18 This musical has been a well-spring for inspiring legal analysis. See Stanley Eugene Fish, Doing What Comes Naturally: Change, Rhetoric, and the Practice of Theory in Literary and Legal Studies (Duke, 1989). Students at Yale used to think that the faculty's motto was "anything you can do, I can do meta."

17 In the course of 350 pages, however, there are a few lapses. At times the authors deploy arguments that seem to reveal more about their visceral behiefs than their theoretical or empirical analysis. For those looking for a glimpse into the authors' souls, I offer the following examples:

(1) The authors repeatedly argue that corporate "[d]ebt puts managers on a shorter

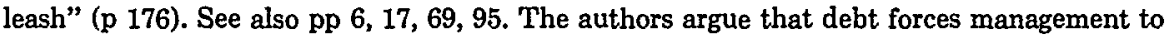
act efficiently in the long run or be faced with the fact that "[e]ventually it must be ground under" ( $p$ 218). The authors are correct that debt puts management on a leash, but $I$ would argue that it is not necessarily a short one, and it certainly doesn't need to force inefficient firms out of the market. If a firm is financed half through debt and half through equity, then managerial inefficiency will be borne almost entirely by the stockholders. If the managers are legally entrenched and announce that they intend to shirk (so that dividends will be cut in half), the shareholders will experience a one time drop in their share price. After the price drops, the shares will then be paying a risk-adjusted market rate of return, so that the shareholders will be indifferent between selling or retaining their shares. The corporation should be able to repay its current debt and continue to roll over the debt into new bond issues indefinitely. The presence of debt does not ensure the corporation's demise or enhance the likelihood that the managers will be replaced. Management cannot shirk so much that it is unable to pay off the debt, but the presence of debt does not effect management's ability to shirk and lower the amount of shareholders' dividends.

(2) In discussing the regulation of disclosure, Easterbrook and Fischel argue: "One cannot leap from the difficulties of a market with asymmetric information to the conclusion that there is need for regulation-even such mild regulation as a prohibition of fraud" ( $p$ 
By focusing on the possible efficiency of muddy defaults, this review has argued that the book's theory of default choice is incomplete. A muddy default rule implemented by courts ex post makes contractual obligations and entitlements contingent on circumstances that are costly to exhaustively predict and write down ex ante (but knowable by courts ex post). A theory of muddy defaults has been deployed to qualify two of the book's central claims. First, an analysis of muddy defaults qualifies the authors' thesis that defaults should be set at what a majority of firms would contract for. ${ }^{48}$ Muddy defaults may be efficient even when a majority of firms want more crystalline unconditional terms of corporate governance, because it is more expensive to affirmatively contract for mud than to passively accept a muddy default.

Second, an appreciation of the constraints on private ex ante contracting undermines the causal theory that competition among states will cause legislatures to pass efficient default rules. Legislatures are even more constrained than individual corporations in writing fully contingent contracts. The trivial rules that legislatures provide ex ante could easily be replicated by the firms themselves by contract. Jurisdictions are much more likely to compete for corporations on the basis of judge-made defaults than on legislature-made defaults-because only the former provides rules that the private parties can't trivially provide for themselves.

The claim that muddy default rules could be efficient is heterodox within the law and economics community. It stems from a prediction that some firms would want courts to implement more

280). This is an especially strange reluctance for contractarians given that fraud prohibitions are such a core part of virtually all contract regimes.

(3) In discussing the efficiency of leaving incumbent management in power after the stockholders" "shares are under water" (i.e. the firm is insolvent), the authors conclude: "Because managers try to enhance their own reputations, we would expect them to be as faithful in the pursuit of creditor interests as they once were in pursuit of shareholders' interests" (p 69). For a book focusing on the economic structure of corporate law, it is odd to expect managers to pursue creditors interests the same as shareholder interests when there are such divergent mechanisms for removing management from solvent and insolvent companies.

(4) In discussing the inefficiency of recent antitakeover statutes, the book concludes: "Delaware's decision to adopt an antitakeover statute will create opportunities for other states. It is no coincidence that California, which has both the largest number of incorporations and by far the largest number of new firms going public, has never had an antitakeover statute" ( $p$ 223). This image of California as outstripping Delaware im an efficiency race is strained; this is, after all, the state that mandates cumulative voting (a rule which for Easterbrook and Fischel inefficiently empowers minority shareholders).

18 The hypothetical contract thesis was also refuted by several of the author's own examples which effectively argued for penalty defaults. See Section IA. 
fully contingent rules than the firms themselves can practicably contract for ex ante. Eminent contract scholars such as Robert Scott and Alan Schwartz would probably disagree with this prediction. ${ }^{49}$ Yet it is important to emphasize that the efficiency arguments in favor of muddy defaults are at their strongest in the corporate context. The traditional arguments in favor of majoritarian defaults are wholly absent. For publicly traded corporations, the contracting parties are likely to acquire complete information about the prevailing defaults, so the need to conform defaults to the parties' expectations drops from the analysis. And as emphasized above, supplying standard form or off-the-rack defaults does not significantly reduce transaction costs, given the insignificant costs of affirmatively contracting for any default that a corporate statute might provide.

Majoritarian concerns are accordingly at their weakest with regard to publicly traded corporations. Using muddy rules as gap fillers might be efficient even if only a minority of firms would prefer ex post judicial determination. At the very least, it should be hard for Easterbrook and Fischel (or other theorists) to argue that muddy rules are less efficient thian default rules that do not make contractual entitlements more fully contingent. Since under this reading corporations can contract around either type of default, the choice of default rules would be unimportant-muddy defaults would merely be as efficient as other rules. Yet even this reading undermines the authors' claim that legislatures could effectively compete over default choice. If corporate defaults are a "wet noodle," Delaware could gain no advantage over other states by discovering and providing the true majoritarian gap filler.

This review has sought to qualify the contractual analysis of the book, not to refute it. Easterbrook and Fischel are worthy heirs to the contractual tradition begun by Coase more than fifty years ago. Their analysis of hypothetical contracting in a broad variety of situations will undoubtedly be the starting point of future corporate scholarship. A decade ago, the important debate in corporate law concerned whether corporate rules should be susceptible to alteration by private contract. In large part because of the scholarship represented in this book, the current debate is no longer about whether corporate law should provide a default-but now what the default should be. My quibbles about the appropriate

19 See, for example, Robert Scott, A Rational Theory of Default Rules for Commercial Contracts, $19 \mathrm{~J}$ Legal Stud 597 (1990); Alan Schwartz, Relational Contracts in the Courts: An Analysis of Incomplete Agreements \& Judicial Strategies, 21 J Legal Stud 271 (1992). 
choice of default rules underscores the success of Easterbrook and Fischel in changing the grounds of the debate and should be taken as a further affirmation of their contribution to this field.

A theme running through this review is that an analysis of efficiency is best carried out by explicitly considering how the equilibrium will respond to alternative presumptive rules. ${ }^{50}$ Only this type of theoretical and empirical inquiry is likely to tell whether and when the choice of defaults matters. The Economic Structure of Corporate Law has paved the way for future scholars undertaking this inquiry.

so Some of the best writing in corporate law still fails to compare the efficiency of alternative defaults. For example, in refuting Easterbrook and Fischel's immutable rule of target passivity, Haddock, Macey and McChesney are agnostic about whether passivity is an effcient default. $73 \mathrm{Va} \mathrm{L} \mathrm{Rev} \mathrm{at} \mathrm{733-37} \mathrm{(cited} \mathrm{in} \mathrm{note} \mathrm{9).} \mathrm{See} \mathrm{also} \mathrm{Jonathan} \mathrm{R.} \mathrm{Macey} \mathrm{and}$ Geoffrey P. Miller, The Fraud-on-the-Market Theory Revisited, 77 Va L Rev 1001, 1010-12 (1991) (failing to analyze whether equilibrium with default warranty of honesty would be more efficient than equilibrium with default of no warranty). 